\title{
Lead and Cadmium Induced Oxidative Stress in the Epididymis and Spleen of Rats: Effects of Sesamol
}

\author{
Fatma Gökçe APAYDIN ${ }^{*}$, Hatice BAŞ², Yusuf KALENDER ${ }^{1}$ \\ ${ }^{1}$ Gazi University, Faculty of Science, Department of Biology, Ankara, Turkey \\ ${ }^{2}$ Yozgat Bozok University, Faculty of Science and Letters, Department of Biology, Yozgat, Turkey \\ ORCID ID: Fatma Gökçe APAYDIN: https://orcid.org/0000-0002-2771-7488; Hatice BAŞ: https://orcid.org/0000-0001-8296-0360; Yusuf \\ KALENDER: https:// orcid.org/0000-0001-5457-0517
}

Received: 21.09 .2020

Accepted: 18.01 .2021

Published online: 31.03 .2021

Issue published: 30.06 .2021

\begin{abstract}
Lead and cadmium are known as environmental pollutants extensively found in food and water that induce hazards to animals' and people's health. Sesamol is a dietary antioxidant that is found in some plants. Epididymis is known to play an important role in the maturation and storage of the sperm. The spleen is an important organ involved in the immune response. The present study aims to analyze the oxidative stress in spleen and epididymis. Therefore, Lead (LN) (90 mg/ $\mathrm{kg}$ bw per day, $\left.1 / 25 \mathrm{LD}_{50}\right)$, Cadmium $\left(\mathrm{CdCl}_{2}\right)\left(3 \mathrm{mg} / \mathrm{kg}\right.$ bw per day, $\left.1 / 25 \mathrm{LD}_{50}\right)$, and sesamol $(50 \mathrm{mg} / \mathrm{kg}$ bw per day) were given to rats by gavage for 28 days. Antioxidant enzyme activities in epididymis and spleen tissues [superoxide dismutase (SOD), catalase (CAT), glutathione peroxidase (GPx) and glutathione $S$ transferase], malondialdehyde (MDA) were investigated at the end of 28 days comparatively with the control group. It is revealed that there is a significant decline in the antioxidant enzymes and increase in MDA levels in the spleen and epididymis tissues of the lead and cadmium treated rats compared to the control group. A small increase in these parameters was also observed in the sesamol treated groups.
\end{abstract}

Keywords: Antioxidants, heavy metals, lipid peroxidation, organ toxicity.

\section{Sıçanların Epididimis ve Dalak Dokularında Kurşun ve Kadmiyuma Bağlı Oksidatif Strese Karşı Sesamolün Etkileri}

\begin{abstract}
Öz: Kurşun ve kadmiyum, hayvan ve insan sağlığına zarar veren gıda ve su kirleticilerinde yaygın olarak bulunan bilinen çevre kirleticileridir. Sesamol, bazı bitkilerde bulunan bir diyet antioksidanıdır. Epididimisin spermin olgunlaşması ve depolanmasında önemli bir rol oynadığı bilinmektedir. Dalak, bağışıklık tepkisinde rol oynayan önemli bir organdır. Bu çalışma, dalak ve epididimdeki oksidatif stresi analiz etmeyi amaçlamaktadır. Bu amaçla sıçanlara kurşun (günde $90 \mathrm{mg} / \mathrm{kg}$ canlı ağırlık, 1/25 LD $D_{50}$ ), kadmiyum (günde $3 \mathrm{mg} / \mathrm{kg}$ canlı ağırlık, $1 / 25 \mathrm{LD}_{50}$ ) ve sesamol (günde $50 \mathrm{mg} / \mathrm{kg}$ canlı ağırlık) verildi. 28 gün boyunca gavaj, 28 gün sonunda epididimis ve dalak dokularındaki antioksidan enzim aktiviteleri [süperoksit dismutaz (SOD), katalaz (CAT), glutasyon peroksidaz (GPx) ve glutatyon S transferaz], malondialdehit (MDA) kontrol grubu ile karşılaştırmalı olarak araştırıldı. Kontrol grubuna göre kurşun ve kadmiyum uygulanan sıçanların dalak ve epididimis dokularında antioksidan enzimlerinde istatistiksel olarak anlamlı bir azalma ve MDA düzeylerinde artış olmuştur. Bu parametrelerde sesamol ile tedavi edilen gruplarda daha az artış gözlenmiştir.
\end{abstract}

Anahtar kelimeler: Antioksidanlar, ağır metal, lipit peroksidasyonu, organ toksisitesi.

\section{Introduction}

Lead and cadmium are extremely toxic and widespread heavy metals used in the environment. Materials containing cadmium are plastic, glass, and metal alloys (Marchlewicz et al., 2004; Merra et al., 2014; Baş \& Kalender, 2016). It has been reported that lead caused some toxicity on reproductive systems (Marchlewicz et al., 2004). It has been known that cadmium causes oxidative damage in many organisms through mechanisms such as inhibition of major anti-oxidative enzymes like catalase (CAT) and superoxide dismutase (SOD) and enzymes that include glutathione (Djuric et al., 2015). Heavy metals have toxic effects on renal cells, hepatocytes, and also on mammalian brain cells. The relationship between metals and toxicity of the kidney, liver, and brain has been demonstrated in previous studies (Apaydin et al., 2016; Uzunhisarcikli et al., 2016; Baş et al., 2015a).

Imbalance between the reactive oxygen species
(ROS) and antioxidant defenses is caused by oxidative stress (Zhou et al., 2011). Many investigations have evaluated the antioxidant activity of various materials using different techniques. Antioxidant compounds are widely used because of their protective roles in the body and against oxidative stress-mediated pathological processes (Gulcin, 2020).

Sesamol (3,4-methylenedioxyphenol), known as a potent antioxidant in sesame seed oil, is also an antiinflammatory agent (Parihar et al., 2006). Sesamol has protective roles on organ injuries (Chu et al., 2010). Sesamol decreases lipid peroxidation and potently reduces oxidative stress (Hsu et al., 2008).

The immune system is very sensitive to toxic substances. Spleen is an organ that takes a role in the immune responses and antibody-production. Lymphocytes in the spleen are activated when presented with foreign antigens (Fang et al., 2010; Merra et al., 2014). 
On the other hand, epididymis plays an important role in sperm maturation and storage. Moreover, many substances are synthesized in the epididymis cells (Zhou et al., 2011). Therefore, in this study, the effects of cadmium and lead on these tissues have been studied. At the same time, it was examined whether sesamol has a role on these effects.

\section{Material and Methods}

\subsection{Animals and chemicals}

90 days of age Male Wistar rats (200-250 g body weight) were purchased from the Laboratory Animals Raising and Experimental Researches Center of Gazi University. All experimental procedures that treated animals were performed in accordance with protocols and guidelines of the Animal Experiments Local Ethics Committee (Protocol no: G.Ü.ET-17.086), Gazi University, Turkey. All rats were housed in plastic cases and fed ad libitum food and water. Cadmium chloride, lead nitrate, and sesamol were obtained from Sigma (St. Louis, MO) and dissolved in distilled water.

\subsection{Animal treatments}

Rats were divided into 8 groups with 6 rats in each group, randomly. Animals were treated with lead nitrate (product code: 1002741224), cadmium chloride (product code: 1002563650), and sesamol (product code: 102085395) orally via gavage. After the experiments, rats were sacrificed under euthanasia by a combination of ketamine and xylazin, then spleen and epididymis tissues were removed for spectrofotometrical analysis. Lead nitrate (90 $\mathrm{mg} / \mathrm{kg} \mathrm{bw}$; 1/25 LD 50 ) (Plastunov \& Zub, 2008; Sharma et al., 2010), cadmium chloride ( $3 \mathrm{mg} / \mathrm{kg}$ bw; $\left.1 / 25 \mathrm{LD}_{50}\right)$ (ElDemerdash et al., 2004), and sesamol (50 mg/ $\mathrm{kg} \mathrm{bw}$ ) (Hemalatha et al., 2013) were given to rats via gavage for 28 days.

\subsection{Biochemical analysis}

The tissues were dissected and washed in sodium phosphate buffer ( $\mathrm{pH}$ 7.2). After washing, samples were taken and stored at $-80^{\circ} \mathrm{C}$ until the analysis. The tissues were homogenized using a teflon homogenizer (Heidolph Silent Crusher M). MDA content and antioxidant enzyme activity were determined by measuring the absorbance of the samples in a spectrophotometer (Shimadzu UV 1700, Kyoto, Japan). All processes were carried out at $4^{\circ} \mathrm{C}$. Lipid peroxidation was determined by malondialdehyde production and measured in spleen and epididymis homogenates according to the method of Ohkawa et al. (1979) based on TBARS formation and it was expressed as MDA content. Superoxide dismutase level in tissues was estimated by the method of Marklund \& Marklund (1974) and its activity was expressed as units/mg protein. Catalase was assayed according to the method of Aebi (1984) and expressed as $\mathrm{mmol} / \mathrm{min} / \mathrm{mg}$ protein of hydrogen peroxide unit to $\mathrm{mmol} / \mathrm{min} / \mathrm{mg}$ protein. Glutathione-S-tranferase enzymes activity was assayed by the method of Habig et al. (1974) and expressed as $\mu \mathrm{mol} / \mathrm{min} / \mathrm{mg}$ protein of CDNB-GSH conjugate formed. Glutathione peroxidase was assayed by the method of Paglia \& Valentine (1987) and its activity was expressed as $\mathrm{nmol} / \mathrm{min} / \mathrm{mg}$ protein.

\subsection{Statistical analyses}

All statistical calculations were done by SPSS 20.0 version
(SPSS Inc., Chicago, IL). The values are expressed as the mean \pm standard deviation (SD). Differences between groups were done by one-way analysis of variance (ANOVA). $\quad \mathrm{P}<0.05$ values were stated statistically significant.

\section{Results}

No mortality was observed in $\mathrm{LN}$ and $\mathrm{CdCl}_{2}$ treated groups. Also, there were no statistically significant differences between the control and sesamol-treated groups in MDA levels and activities of SOD, GST, CAT, and GPx in epididymis and spleen of rats (Fig. 1-4).

Matched against with the control group, there were statistically significant enhancing in MDA levels and decreasing in activities of antioxidant enzymes in LN and/or $\mathrm{CdCl}_{2}$ treated groups of epididymis of rats. Parameters that were analyzed in this study were more altered in $\mathrm{LN}+\mathrm{CdCl}_{2}$ treated rats. Application of sesamol with $\mathrm{LN}$ or $\mathrm{CdCl}_{2}$ reversed these changes partially against $\mathrm{LN}$ or $\mathrm{CdCl}_{2}$ used groups but protective effect of sesamol was seen only on GST activity against $\mathrm{LN}+\mathrm{CdCl}_{2}$ group. Sesamol did not show a protective effect on other parameters against the group in which lead and mercury were used together (Fig. 1 and 3).

Figures 2 and 4 exhibit that the anti-oxidative activities of enzyme (SOD, GST CAT, and GPx) and MDA levels showed significant difference among groups of spleen of rats. $\mathrm{LN}$ and $\mathrm{CdCl}_{2}$ treated groups compared to the control group was observed statistically significant decrease on enzyme activities and increase on MDA levels. These changes were higher when $\mathrm{LN}$ plus $\mathrm{CdCl}_{2}$ cotreated. A significant elevation was observed in SOD, GST CAT, and GPx activities and lower in MDA level at the end of the experimental period in sesamol treated group compared to $\mathrm{LN}$ or $\mathrm{CdCl}_{2}$ treated groups. However, the protective effect of sesamol against $\mathrm{LN}+\mathrm{CdCl}_{2}$ group was seen on only CAT, GPx, and MDA levels.

\section{Discussion}

Heavy metals are commonly used generally in world and affect the function and damage the structure of many organs by causing oxidative damages (Garcia-Nino \& Pedraza-Chaverri, 2014; Apaydin et al., 2015; Baş et al., 2015b). Lead and cadmium treatments are consistent with oxidative damage in various tissues (Merra et al., 2014; Djuric et al., 2015). In previous studies, it has been shown that cadmium administration causes an increase in testicular $\mathrm{O}_{2}{ }^{--}$concentrations by different doses (Djuric et al., 2015). Cadmium interferes with protein metal-binding functional groups altering essential bio-metals homeostasis as well as the activities of corresponding metallic-enzymes, metallothioneins (MTs) overproduction, and competing with essential bioelements for protein binding sites in different organs (Djuric et al., 2015).

When metals and antioxidants are applied together, it is observed that the toxic effect of metals is reduced (Apaydin et al., 2016; Garcia-Nino \& Pedraza-Chaverri, 2014; Kalender et al., 2015). In previous studies, researchers reported that the reason for the decrease in the antioxidant enzyme activity is due to the metals binding to ions in these enzymes (Djuric et al., 2015). 


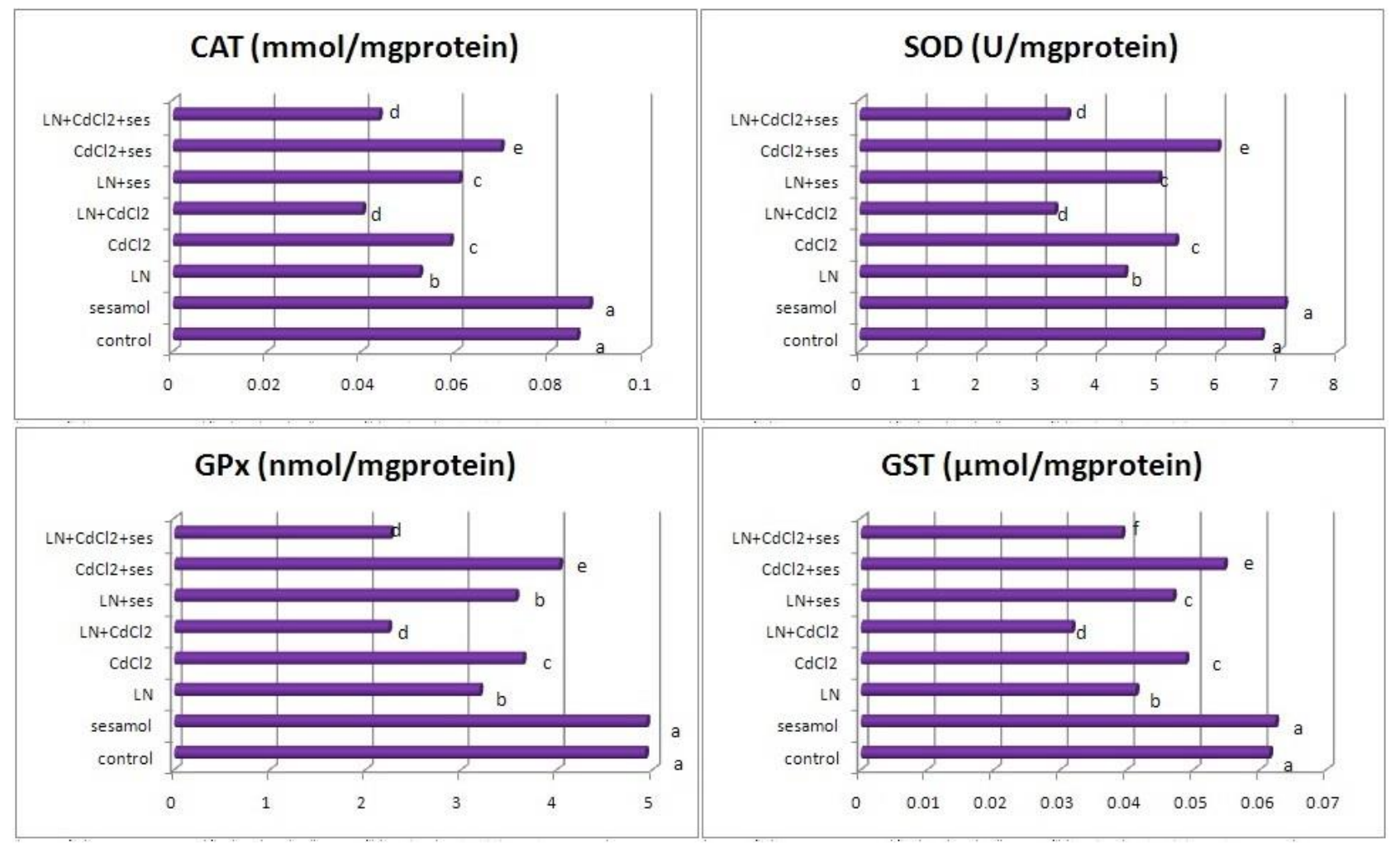

Figure 1. Preventive effects of sesamol (ses) against lead nitrate (LN) and cadmium chloride $\left(\mathrm{CdCl}_{2}\right)$ on antioxidant enzyme activities in epididymis of rats. Each bar represents mean \pm SD (Significance at $\mathrm{P}<0.05$ ). Columns superscripts with different letters are significantly different.

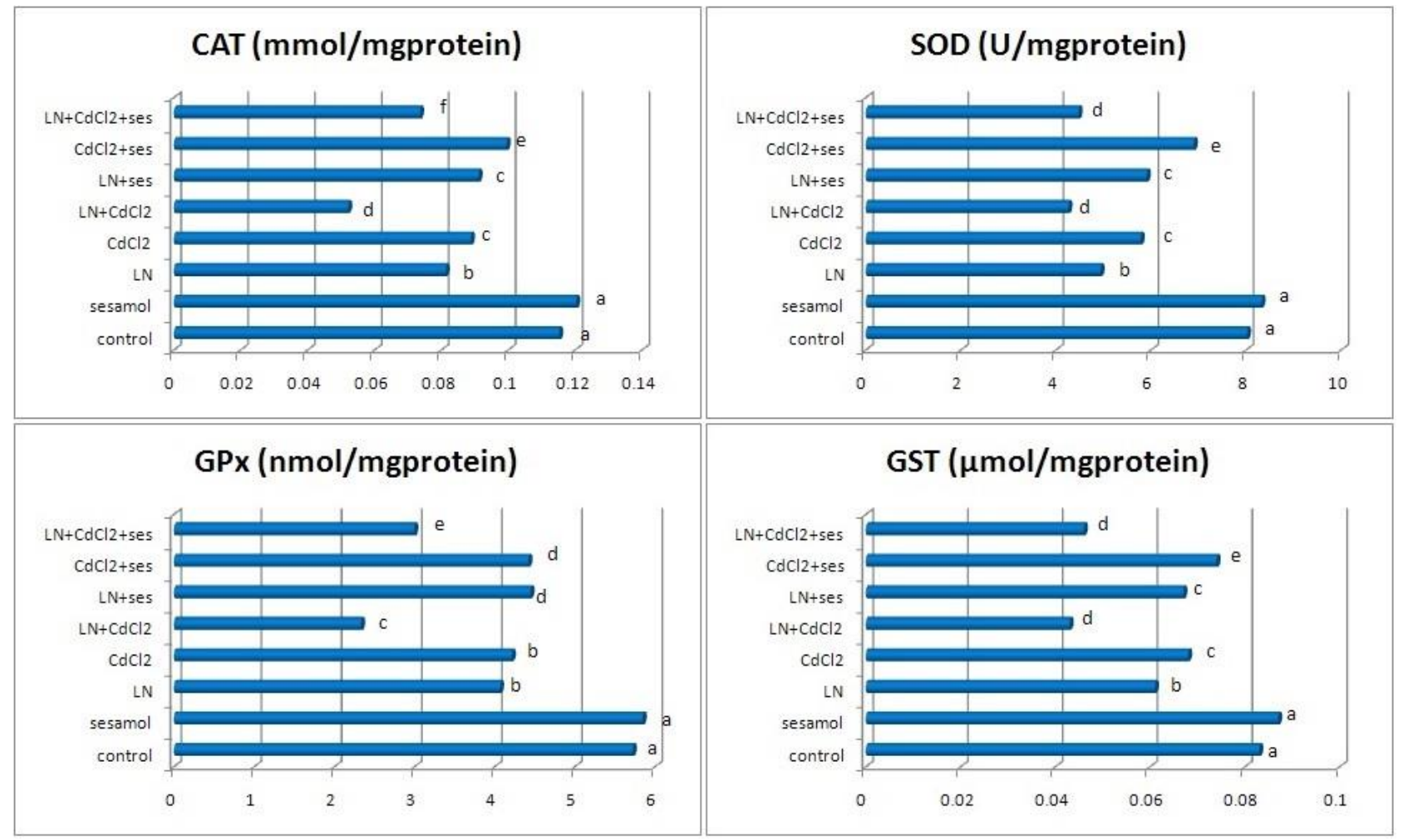

Figure 2. Preventive effects of sesamol (ses) against lead nitrate (LN) and cadmium chloride $\left(\mathrm{CdCl}_{2}\right)$ on antioxidant enzyme activities in spleen of rats. Each bar represents mean \pm SD (Significance at $\mathrm{P}<0.05$ ). Columns superscripts with different letters are significantly different.

Lipid peroxidation is known to damage the integrity of cellular membranes, leading to the leakage of cytoplasmic enzymes and it also a marker of cellular oxidative damage (Tunali \& Yanardag, 2006; Neogy et al., 2008). Antioxidant enzymes are primarily defense systems that protect biological macromolecules Antioxidant enzymes are primarily defense system which prevents biological macromolecules (Neogy et al., 2008). Cells include many antioxidant enzymes such as catalase, superoxidase dismutase, glutathione-S-transferase, and glutathione peroxidase (Neogy et al., 2008). 


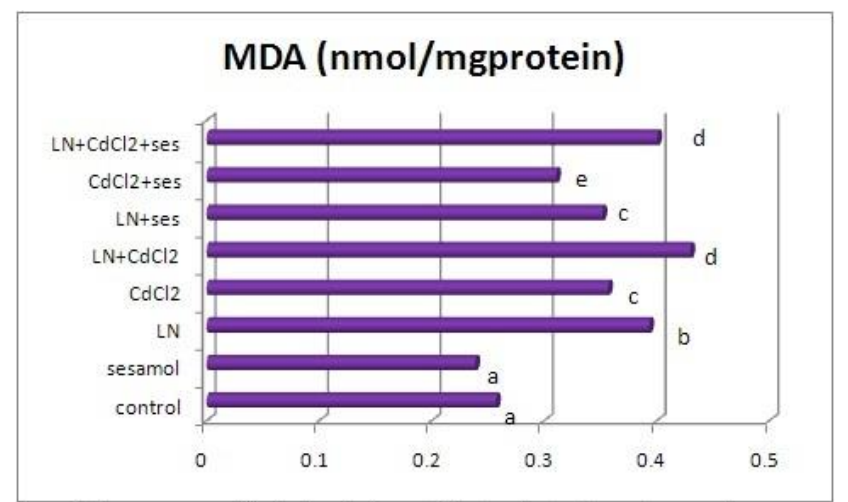

Figure 3. Preventive effects of sesamol (ses) against lead nitrate (LN) and cadmium chloride $\left(\mathrm{CdCl}_{2}\right)$ on MDA levels in epididymis of rats. Each bar represents mean $\pm S D$ (Significance at $P<0.05$ ). Columns superscripts with different letters are significantly different.

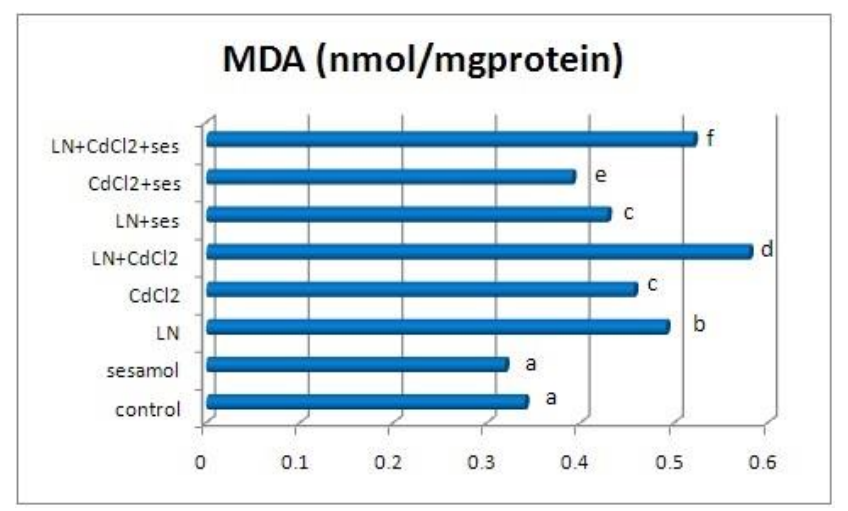

Figure 4. Preventive effects of sesamol (ses) against lead nitrate (LN) and cadmium chloride $\left(\mathrm{CdCl}_{2}\right)$ on MDA levels in spleen of rats. Each bar represents mean \pm SD (Significance at $\mathrm{P}<0.05$ ). Columns superscripts with different letters are significantly different.

It is known that supplementation of an external source of antioxidants may offer some protection for cell damages. The term antioxidant refers to a wide spectrum of compounds which neutralizes free radical injuries (Garcia-Nino \& Pedraza-Chaverri, 2014).

In the present study, administration of lead and cadmium increased lipid peroxidation in the epididymis and spleen. Similarly, environmental contaminants caused negative effects via increasing lipid peroxidative damages and caused differences in antioxidant levels in the epididymal sperm the male reproductive system (Latchoumycandane et al., 2003), and spleen tissues (Merra et al., 2014). In addition, splenotoxicity is important for many subchronic and chronic experiments (Tunali \& Yanardag, 2006; Ma et al., 2008). It has also been shown in many studies that the biomarker enzymes measured in the study can be induced in heavy metal exposure (Agarwal et al., 2010).

Epididymis and spleen are affected by subacute cadmium and lead intoxication. It may be due to oxidative stress and lipid peroxidation causing serious harm to these tissues. When heavy metals are used together with sesamol, we showed that ameliorative effect.

Ethics committee approval: This study was performed in accordance with ethical standards of animal experiments. Legal research ethics committee approval permissions for the study were obtained from the Gazi University, Animal Experiments Local Ethics Committee (No: G.Ü.ET-17.086).

Conflict of interest: The authors declares that there is no conflict of interest.

\section{References}

Aebi, H. (1984). Catalase in vitro. Methods in Enzymology, 105, 121-126. https://doi.org/10.1016/S0076-6879(84)05016-3

Agarwal, R., Goel, S.K., Chandra, R., \& Behari, R.J. (2010). Role of vitamin $\mathrm{E}$ in preventing acute mercury toxicity in rat. Environmental Toxicology and Pharmacology, 29, 70-78. https://doi.org/10.1016/i.etap.2009.10.003

Apaydın, F. G., Bas, H., Kalender, S., \& Kalender, Y. (2016). Subacute effects of low dose lead nitrate and mercury chloride exposure on kidney of rats. Environmental Toxicology and Pharmacology, 41, 219-224. https://doi.org/10.1016/j.etap.2015.12.003

Apaydin, F.G., Kalender, S., Bas, H., Demir, F., \& Kalender, Y. (2015). Lead nitrate induced testicular toxicity in diabetic and non-diabetic rats: protective role of sodium selenite. Brazilian Archives of Biology and Technology, 58 (1), 68-74. https://doi.org/10.1590/S1516$\underline{8913201400025}$

Baş, H., \& Kalender, Y. (2016). Nephrotoxic effects of lead nitrate exposure in diabetic and nondiabetic rats: Involvement of oxidative stress and the protective role of sodium selenite. Environmental Toxicology, 31(10), 1229-1240. https://doi.org/10.1002/tox.22130

Baş, H., Kalender, S., Karaboduk, H., \& Apaydın, F. G. (2015a). The effects on antioxidant enzyme systems in rat brain tissues of lead nitrate and mercury chloride. Gazi University Journal of Science, 28(2), 169-174.

Baş, H., Kalender, Y., Pandir, D., \& Kalender, S. (2015b). Effects of lead nitrate and sodium selenite on DNA damage and oxidative stress in diabetic and non-diabetic rat erythrocytes and leucocytes. Environmental Toxicology and Pharmacology, 39 (3), 1019-1026. https://doi.org/10.1016/j.etap.2015.03.012

Chu, P., Chien, S., Hsu, D., \& Liu, M. (2010). Protective effect of sesamol on the pulmonary inflammatory response and lung injury in endotoxemic rats. Food and Chemical Toxicology, 48, 1821-1826. https://doi.org/10.1016/j.fct.2010.04.014

Djuric, A., Begic, A., Gobeljic, B., Stanojevic, I., Ninkovic, M., Vojvodic, D. ... Djukic, M. (2015). Oxidative stress, bioelements and androgen status in testes of rats subacutely exposed to cadmium. Food and Chemical Toxicology, 86, 25-33. https://doi.org/10.1016/j.fct.2015.09.004

El-Demerdash, F.M., Yousef, M.I., Kedwany, F.S., \& Baghdadi, H.H. (2004). Cadmium induced changes in lipid peroxidation, blood hematology, biocheemalatical parameters and semen quality of male rats: protective role of vitamin E and b-carotene. Food and Chemical Toxicology, 42, 15631571. https:// doi.org/10.1016/j.fct.2004.05.001

Fang, X., Feng, Y., Wang, J., \& Dai, J. (2010). Perfluorononanoic acidinduced apoptosis in rat spleen involves oxidative stress and the activation of caspase-independent death pathway. Toxicology, 267, 5459. https://doi.org/10.1016/i.tox.2009.10.020

Garcia-Nino, W.R., \& Pedraza-Chaverri, J. (2014). Protective effect of curcumin against heavy metals-induced liver damage. Food and Chemical Toxicology, 69, 182-201. https://doi.org/10.1016/i.fct.2014.04.016

Gulcin, İ. (2020). Antioxidants and antioxidant methods: an updated overview. Archives of Toxicology, 94, 651-715. https://doi.org/10.1007/s00204-020-02689-3

Habig, W.H., Pabst, M.J., \& Jakoby, W.B. (1974). Glutathione-S-transferases: the first enzymatic step in mercapturic acid formation. The Journal of Biological Chemistry, 249, 7130-7139.

Hemalatha, G., Pugalendi, K.V., \& Saravanan, R. (2013). Modulatory effect of sesamol on DOCA-salt-induced oxidative stress in uninephrectomized hypertensive rats. Molecular and Cell Biochemistry, 379, 255-265. https://doi.org/10.1007/s11010-013-1647-1

Hsu, D., Wan, C., Hsu, H., Lin, Y., \& Liu, M. (2008). The prophylactic protective effect of sesamol against ferric-nitrilotriacetate-induced acute renal injury in mice. Food and Chemical Toxicology, 46, 2736-2741. https://doi.org/10.1016/j.fct.2008.04.029

Kalender, S., Apaydın, F. G., Baş, H., \& Kalender, Y. (2015). Protective effects of sodium selenite on lead nitrate-induced hepatotoxicity in diabetic and non-diabetic rats. Environmental Toxicology and Pharmacology, 40, 568-574. https://doi.org/10.1016/j.etap.2015.08.011

Latchoumycandane, C., Chitra, K.C., \& Mathur, P.P. (2003). 2,3,7,8Tetrachlorodibenzo-p -dioxin (TCDD) induces oxidative stress in the epididymis and epididymal sperm of adult rats. Achieves of Toxicology, $77,280-284$ 
Ma, H., Wang, J., Abdel-Rahman, S., Boor, P.J., \& Khan, M.F. (2008). Oxidative DNA damage and its repair in rat spleen following subchronic exposure to aniline. Toxicology and Applied Pharmacology, 233, 247-253. https://doi.org/10.1016/j.taap.2008.08.010

Marchlewicz, M., Michalska, T., \& Wiszniewska, B. (2004). Detection of lead-induced oxidative stress in the rat epididymis by $\begin{array}{llr}\text { chemiluminescence. } & \text { Chemosphere, 57, 1553-1562. }\end{array}$ https://doi.org/10.1016/j.chemosphere.2004.08.102

Marklund, S. \& Marklund, G. (1974). Involvement of the superoxide anion radical in the autoxidation of pyrogallol and a convenient assay for superoxide dismutase. European Journal of Biochemistry, 47, 469-474. https://doi.org/10.1111/j.1432-1033.1974.tb03714.x

Merra, E., Calzaretti, G., Bobba, A., Storelli, M.M., \& Casalino, E. (2014). Antioxidant role of hydroxytyrosol on oxidative stress in cadmiumintoxicated rats: different effect in spleen and testes. Drug and Chemical Toxicology, 37, 420-426. https:// doi.org/10.3109/01480545.2013.878950

Neogy, S., Das, S., Mahapatra, S.K., Mandal, N., \& Roy, S. (2008). Amelioratory effect of Andrographis paniculata Nees on liver, kidney, heart, lung and spleen during nicotine induced oxidative stress. Environmental Toxicology and Pharmacology, 25, 321-328. https://doi.org/10.1016/j.etap.2007.10.034

Ohkawa, H., Ohishi, N., \& Yagi, K. (1979). Assay for lipid peroxides in animal tissues by thiobarbituric acid reaction. Analytical Biochemistry, 95, 351-358.

Paglia, D.E., \& Valentine, W.N. (1987). Studies on the quantative and qualitative characterization of glutathione peroxidase. Journal Laboratory Medicine, 70, 158-165.

Parihar, V.K., Prabhakar, K.R., Veerapur, V.P., Kumar, M.S., Reddy, Y.R., Joshi, R., ... Rao, C.M., (2006). Effect of sesamol on radiation-induced cytotoxicity in Swiss albino mice. Mutation Research, 611, 9-16. https://doi.org/10.1016/j.mrgentox.2006.06.037

Plastunov, B., \& Zub, S. (2008). Lipid peroxidation processes and antioxidant defense under lead intoxication and iodine-deficient in experiment. Anales Universitatis Mariae Curie Sklodowska Lublin-polonia, $21,215-217$.

Sharma, V., Sharma, A., \& Kansal, L. (2010). The effect of oral administration of Allium sativum extracts on lead nitrate induced toxicity in male mice. Food and Chemical Toxicology, 48, 928-936. https://doi.org/10.1016/j.fct.2010.01.002

Tunali, S., \& Yanardag, R. (2006). Effect of vanadyl sulfate on the status of lipid parameters and on stomach and spleen tissues of streptozotocininduced diabetic rats. Pharmacological Research 53, 271-277. https://doi.org/10.1016/j.phrs.2005.12.004

Uzunhisarcikli, M., Aslantürk, A., Kalender, S., Apaydın, F.G., \& Baş, H. (2016). Mercuric chloride induced hepatotoxic and hematologic changes in rats: The protective effects of sodium selenite and vitamin E. Toxicology and Industrial Health, 32, 1651-1662. https://doi.org/10.1177/0748233715572561

Zhou, D., Wang, H., \& Zhang, J. (2011). Di-n-butyl phthalate (DBP) exposure induces oxidative stress in epididymis of adult rats. Toxicology and Industrial Health, 27 (1), 65-71. https://doi.org/10.1177/0748233710381895 